\title{
Longitudinal characterisation of a model of chronic allergic lung inflammation in mice using imaging, functional and immunological methods
}

\author{
Kumar Changani ${ }^{1,2^{*}}$, Catherine Pereira ${ }^{3}$, Simon Young ${ }^{4}$, Robert Shaw ${ }^{1}$, Simon P Campbell ${ }^{1,2}$, Kashmira Pindoria $^{1,2}$,
} Steve Jordan ${ }^{5,3}$, Katherine Wiley ${ }^{3}$, Sarah Bolton ${ }^{3}$, Tony Nials ${ }^{1}$, Michael Haase ${ }^{1,2}$, Mike Pedrick ${ }^{2}$, Richard Knowles ${ }^{1,3}$

From 2nd Cross Company Respiratory Symposium

Horsham, UK. 6-7 September 2012

The present study investigated the role that imaging could have for assessing lung inflammation in a mouse model of a house dust mite (HDM) provoked allergic inflammation. Inflammation is usually assessed using terminal procedures such as bronchoalveolar lavage (BAL) and histopathology; however, magnetic resonance imaging (MRI) and computed tomography (CT) methods have the potential to allow longitudinal, repeated study of individual animals. Female BALB/c mice were administered daily either saline, or a solution of mixed HDM proteins sufficient to deliver a dose of $12 \mu \mathrm{g}$ or $25 \mu \mathrm{g}$ total HDM protein \pm budesonide $(1 \mathrm{mg} / \mathrm{kg}$, during weeks $5-7)$ for 7 weeks. Airway hyper- responsiveness (AHR) and IgE measurements were taken on weeks 3, 5 and 7. Following the last imaging session BALs were taken and lungs prepared for histology. MRI showed a gradual weekly increase in lung tissue intensity (LTI) in animals treated with HDM compared to control. The 25ug HDM group showed a continual significant increase in LTI between weeks 3-7, the $12 \mathrm{ug}$ HDM treated group showed similar rates of increase, and plateaued by week 5 (Figure 1). A corresponding increase in AHR, cell counts and IgE were observed. CT showed significant increases in lung tissue density from week 1 of HDM and this was maintained throughout the 7 weeks. Budesonide treatment reversed the increase in tissue density (Figure 2). MRI and CT therefore provide non-invasive sensitive methods for longitudinally assessing lung inflammation. Lung tissue changes could be compared directly with the classical

\footnotetext{
* Correspondence: kumar.k.changani@gsk.com

'Respiratory Therapeutic Area, GlaxoSmithKline, Gunnels Wood Road,

Stevenage, Hertfordshire, SG1 2NY, UK

Full list of author information is available at the end of the article
}
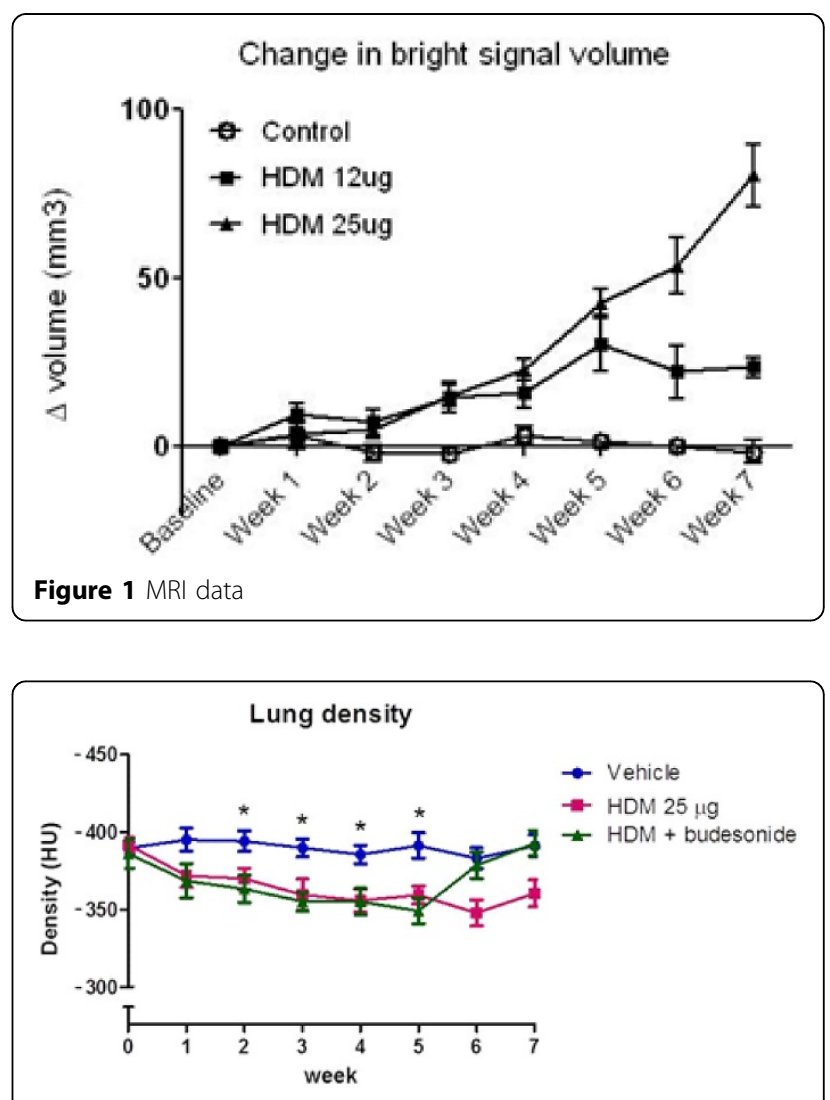

Figure $2 \mathrm{CT}$ data

functional and inflammatory readouts allowing more accurate assessments to be made within each animal and provide a clinically translatable approach. 


\section{Authors' details}

${ }^{1}$ Respiratory Therapeutic Area, GlaxoSmithKline, Gunnels Wood Road, Stevenage, Hertfordshire, SG1 2NY, UK. ${ }^{2}$ Platform Technology and Science, GlaxoSmithKline, Gunnels Wood Road, Stevenage, Hertfordshire, SG1 2NY, UK. ${ }^{3}$ AstraZeneca, Alderley Park, Macclesfield SK10 4TG, UK. ${ }^{4}$ Arachos Pharma, Stevenage Bioscience Catalyst, Gunnels Wood Road, Stevenage,

Hertfordshire, SG1 2FX, UK. ${ }^{5}$ Huntingdon Life Sciences, Woolley Road,

Huntingdon, Cambridgeshire, PE28 4HS.

Published: 14 August 2013

doi:10.1186/1476-9255-10-S1-P4

Cite this article as: Changani et al:: Longitudinal characterisation of a

model of chronic allergic lung inflammation in mice using imaging,

functional and immunological methods. Journal of Inflammation 201310

(Suppl 1):P4

\section{Submit your next manuscript to BioMed Central} and take full advantage of:

- Convenient online submission

- Thorough peer review

- No space constraints or color figure charges

- Immediate publication on acceptance

- Inclusion in PubMed, CAS, Scopus and Google Scholar

- Research which is freely available for redistribution

Submit your manuscript at www.biomedcentral.com/submit 